\title{
ポリブタジエンのミクロ構造の赤外 吸収スペクトルによる分析法について
}

\section{大塚齊之助* - 田中康之 ${ }^{* *}$ ・吉本敏雄 $* * *$ 藤森 惊****}

\section{1. はじめに}

1,3-ブタジェンは重合する場合のモノマー単位の結合 様式によってつぎの 3 種の立体配置をとることが知られ ている。ところがポリブタジェンの物理的性質はその主 鎖中に含まれているこれらの構造単位の割合によって大 きく支配される1〉。たと壳ばシスー1, 4 ポリブタジェンは<smiles>CCCC</smiles>

シス- 1,4 型<smiles>CCCC</smiles>

トランス-1, 4 型<smiles>CCCC</smiles>

1,2 型(ビニル型)
一般に天然ゴム (シス $-1,4$ ポリイソプレン) と類似した ゴム状を示すが，トランス $-1,4$ ポリブタジェンはむしろ プラステック性を特びている。立体規則性重合技術のめ ざましい発展により最近ではほにんどシス- 1,4 付加の みからなるポリブタジェンが各国に拉いて工業生産され るようになり，わが国に特いてもその工業化が急がれて いる。

ポリブタジェンの主鎖中に分布するミクロ構造単位の 定量には, 赤外分光光度計を使用する分光光度法がきわ めて有力である。このため現在屯でに多数の研究者によ って赤外分光光度法によるポリブタジェンのミクロ構造 の分析方法が研觉されてきた。しかし赤外分光光度法に おいては, 赤外線スペクトルの幅がスペクトル幅に換算 されたスリットの愊 (spectral slit width) と同程度で あるため, 吸収の強さが装置, 测定条件(すなわち測定 時の分解能）によって変化し，文献記載の吸光係数を無 批判にその末李転用することができないららみがある。 そのう充刘象がポリマーのミクロ構造であるため純粋な 構造単位をもつ標準物質の入奉が活とんぞ不可能であ り，その他原理的にも，試料調製法にも単純な混合物の 場合にはみられない多くの制限がある。筆者らはポリブ

* 日本合成ゴム株式会社四日市研究所主任研究員・理博

** 同所研究員

*** ブリヂストンタイヤ株式会社技術本部研究部・理博

$* * * *$ 同社同部
タジェンの赤外吸収スペクトルによる分析法を各種の方 法で行なって，測定方法，条件などを検討することを目 的として実験した。

本稿ではブリデストンタイヤ (BS) 研究部および日本 合成ゴム (JSR) 研究所の共同研究を行ない，6 種以上の シスス $-1,4$ ポリブタジェン共通試料について，5 種の赤外 分光光度計を使用して得た経験を中心に，ポリブタジェ ンのミクロ構造分析の問題点にふれてみようと思う。

\section{2. 原理}

赤外分光光度法も通常の分光光度法の場合と同椂: Bouguer-Beer の法則が基礎になっている。この法則は 試料による吸収の強さがあまり大きくないかぎり一般に 成立し, 光路長 $t$ のセルに溶媒のみを入れたときの透過: 光の強さを $I_{0}$, 同じセルに濃度 $c$ の溶液を入れたとき の透過光の強さを $I$ とすれば

$$
D=\log \frac{I_{0}}{I}=k c t
$$

とあらわされる。ここで $D$ は吸光度, $k$ は吸光係数で める。

混合系に执いては多くの場合（成分間にとくに強い相 互作用のないかぎり）冬成分の吸光度には加成性が成立. するので，いま $n$ 個の成分よりなる混合系について波 長 $\lambda_{i}$ で光路長 $t_{i}$ のセルを使用して测定した吸光度 $D_{i_{i}}$ は

$$
D_{i_{i}}=\sum_{j=1}^{n} k_{i j} c_{j} t_{i}
$$

となる。ここで $j$ は成分を表わしている。 3 成分系にお いて各成分の key band を $\lambda_{1}, \lambda_{2}, \lambda_{3}$ とすれば

$$
\left.\begin{array}{l}
D_{\lambda_{1}}=k_{11} c_{1} t_{1}+k_{12} c_{2} t_{1}+k_{13} c_{3} t_{1} \\
D_{\lambda_{2}}=k_{21} c_{1} t_{2}+k_{22} c_{2} t_{2}+k_{23} c_{3} t_{2} \\
D_{\lambda_{3}}=k_{31} c_{1} t_{3}+k_{32} c_{2} t_{3}+k_{33} c_{3} t_{3}
\end{array}\right\}
$$

が得られる。この連立方程式を解くと各成分の濃度 $c_{1}$, $c_{2}, c_{3}$ が求められるわけである。(3) 式の $k_{i j} t_{i}$ は単純. な混合物の場合にはそれぞれ純品について光路長既知の.

「高分子」 
セルを用い，濃度を変えて吸光度を測定して直線関係が 得られればその勾配より求められる。しかしポリブタジ エンのミクロ構造分布の分析の上うに純品が得がたい場 合にはこれそ類似の構造をむつ同族体ないし低分子化合 物で代用する group type analysis の方法を適用する ことになる。

ポリブタジェンのシス-1, 4, トランス- 1,4 㧊よび 1,2 構造の分析のために選ばれた key band は二重結合し ている炭素に結合した水素原子の面外変角振動に拺属さ れている。

これらの吸収は一般に二重結合している炭素原子に結 合した他の置換基の種類によりピークの位置や強度が多 少変化する。ポリブタジェンにおいても各棈造単位の分 布状態や相対量によって少し変化することがみとめられ ている。

Hampton $^{2)}$ は標準物質として種々の低分子オレフィ ンを用いて key band として $10.35 \mu, 11.0 \mu$ 乾よび $13.8 \mu$ を選び, Binder ${ }^{3)}$ は $10.35 \mu, 11.0 \mu$ 於よび $14.70 \mu$ を選んだ。Richardson ${ }^{4)}$ は $10.35 \mu$ と $11.0 \mu$ をとれぞ れトランス $-1,4$ と 1,2 の key band として測定しシ ス-1,4 含量は $100 \%$ より差し引いて求めた。以上の方 法はいずれる低分子オレフィンを標準物質として吸収係 数を求めて和り, 乳化重合, アルカリ金属重合またはア ルフィン重合のポリブタジェンのミクロ構造分析に利用

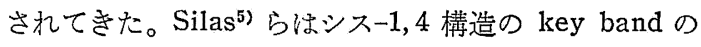
吸光係数として 12.0 15.75 $\mu$ に広がった吸収帯の面積 吸光率を用いることを提案した。この方法は経験的では あるが良好な結果を得ている。特に標準物質として立体 規則性重合により得られた高い割合にそれぞれの構造を
もつポリブタジェンを使用している点で前 3 者より進歩 した方法である。Morero ${ }^{6)}$ らは標準物質としてさらに 純度の高い立体規則性ポリマーを使用して key band と してトランス-1, 4 には $10.34 \mu$ を, 1,2 には 10.95 $10.98 \mu$ にある peak max. を, シス-1, 4 には 13.50 $13.65 \mu$ にある peak max. をとる方法を提案した。第 1 表には代表的な分析法の key band と穴の吸収係数と を示す。各方法はかなり異なった吸光係数を使用してい ることがわかる。標準物質として純度の高い各構造のポ リブタジェンを使用している点で Morero らの方法がも っともすぐれていると考觉られる。

以下の分析は Morero 法に徉って Morero の吸光係 数によって行なわれた分析值を示す。

\section{3. 分析方法の概要}

\section{3-1. 試料の調製}

ポリマー中の不純物, ダル分を除くため, ポリマーの 精製を行なうことが必要である。この実験では, ポリマ 一の $0.5 \sim 1.0 \%$ のベンゼンまたはトルエン溶液を 200 メッシュのステンレス金網でロ過し，口液を凍結乾燥ま たはメタノールを大過剩に加えて得た沈殿ポリマーを室 温で減圧乾燥した。油入りゴムは暗所で 24 時問アセト ン抽出を行ない, その不溶部を用いた。

ポリブタジェンのミクロ構造が分子量の分布状態と関 係していることが Natta らによって報告されているの で7)，分析に用いる試料は，精製によって低分子量が多 く失われ彷ようにする必要がある。

赤外測定用の溶剂は市販の特級二硫化炭素を塩化カル シウムで乾燥, 葵留して用いた。溶液濃度は用いるセル

第 1 表 各種分析法の吸光係数 ${ }^{\mathrm{a})}$ の比較

\begin{tabular}{|c|c|c|c|c|}
\hline & key band $(\mu)$ & 10.35 & $10.95 \sim 10.98^{b)}$ & $13.50 \sim 13.65^{\mathrm{b})}$ \\
\hline Morero $^{\mathrm{d})}$ & $\begin{array}{c}\text { トランス }-1,4 \\
1,2 \\
\text { シス }-1,4\end{array}$ & $\begin{array}{l}2.33 \\
0.0828 \\
0.0609\end{array}$ & $\begin{array}{l}0 \\
2.67 \\
0.0107\end{array}$ & $\begin{array}{l}0 \\
0.0231 \\
0.573\end{array}$ \\
\hline & key band $(\mu)$ & 10.34 & 11.0 & 13.8 \\
\hline Hampton & $\begin{array}{c}\text { トランス-1,4 } \\
1,2 \\
\text { シス-1, } 4\end{array}$ & $\begin{array}{l}2.542 \\
0.098 \\
0.058\end{array}$ & $\begin{array}{l}0.055 \\
3.193 \\
0.037\end{array}$ & $\begin{array}{l}0.007 \\
0.050 \\
0.551\end{array}$ \\
\hline & key band $(\mu)$ & 10.34 & 11.0 & $12.0 \sim 15.75^{\mathrm{c})}$ \\
\hline Silas & $\begin{array}{l}\text { トランス }-1,4 \\
1,2 \\
\text { シス-1, } 4\end{array}$ & $\begin{array}{l}2.46 \\
0.124 \\
0.0814\end{array}$ & $\begin{array}{l}0.0444 \\
3.40 \\
0.0351\end{array}$ & $\begin{array}{l}0.0159 \\
0.0859 \\
0.187\end{array}$ \\
\hline
\end{tabular}

a) 単位 $\left(\mathrm{g}^{-1} \cdot l \cdot \mathrm{cm}^{-1}\right)$
b) ピークの $\max$. における吸光係数
c) 面積吸光率 $\log \left(\int I_{0} d \lambda / \int I d \lambda\right)$
d) 原報記載の吸光係数は 1 ケタ小数点位置が小さくでているので, この表では修正してある。

Vol. 13, No. 145 
の厚さ，シス-1,4\%によっても異なるが，透過率で 30 〜80\% に key band の吸収が現われるようにしなけれ ばならない。この場合, 操作中に溶液濃度が変化しない 上う注意しなければならない。

\section{3-2. 測定方法}

セルは $\mathrm{NaCl}$ 固定セル $0.5 \mathrm{~mm}$ または $1 \mathrm{~mm}$ セルを 用い, 厚さは干渉縞で測定した。 reference 側认は可変 セルまたはペアーセルを用いた。各 key band の吸光度 は両方のセルに溶媒のみを入れた場合の吸光度を $I_{0}$ と し, 試料側に溶液, reference 侧に溶媒のみを入れた場 合の吸光度を $I$ として求めた。シスー1,4 の key band はシス $-1,4 \%$ の低い場合, 低液数側に少し移動する傾向 を示すが，いずれの場合も吸光度は吸収のピークの位置 を測定した。シスー 1,4 ポリブタジェンの典型的な赤外 スペクトルを第 1 図に示す。

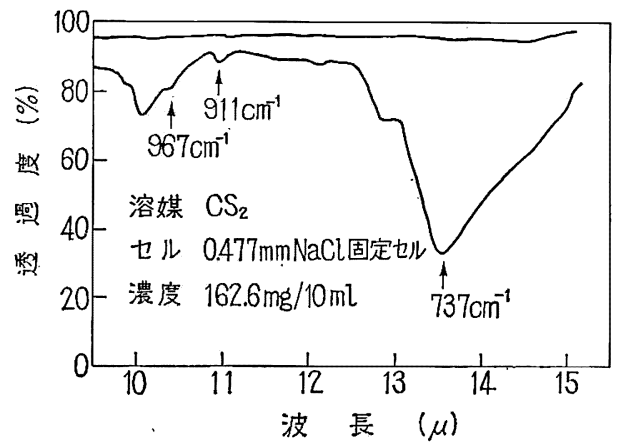

第 1 図 シス-1,4 ポリブタジェンの 赤外吸収スペクトル

\section{3-3. 計算方法}

第 1 表に示した Morero の吸光係数を用いて，直接 シス $-1,4 ， 1,2$, トランス-1, 4\% が求められるように式 を変換すると次式となる。

$$
\begin{aligned}
& C=\left(0.17455 \cdot D_{C}-0.00151 \cdot D_{V}\right) \times \frac{10^{2}}{l} \\
& V=\left(0.03746 \cdot D_{V}-0.00070 \cdot D_{C}\right) \times \frac{10^{2}}{l}
\end{aligned}
$$

$$
T=\left(0.04292 \cdot D_{T}-0.00129 \cdot D_{V}-0.00454 \cdot D_{C}\right) \times \frac{10^{2}}{l .}
$$

ただし

$$
\begin{aligned}
& \left\{\begin{array}{l}
D_{T}=D_{10.34} \ldots \ldots \ldots .10 .34 \mu \text { の吸光度 } \\
D_{V}=D_{10.95}{ }_{10.98} \ldots 10.95 \sim 10.98 \mu \text { 間のピークの吸光度 } \\
D_{C}=D_{10.50 ~ 13.65} \ldots 13.50 \sim 13.65 \mu
\end{array}\right. \\
& l: \text { セル長 }(\mathrm{cm}) \quad p \text { ：ポリマー }(\mathrm{mg} / 10 \mathrm{cc}) \\
& \begin{cases}\text { シス }-1,4 \% & =\frac{C}{P} \cdot 100 \\
1,2 \% & =\frac{V}{P} \cdot 100 \\
\text { トランス }-1,4 \% & =\frac{T}{P} \cdot 100\end{cases}
\end{aligned}
$$

\section{4. 装置・操作による誤差}

前述したように吸光光度法で物質を定量分析する場 合, 定められた吸光係数がいずれの分光器にも適応し, 通常の操作条件で使用して結果がみな一致するというこ とは保証されていない。Perkin-Elmer 21 型赤外分光器 によって求めた Morero の吸泊係数を他の装置, 操作条 件で用いた場合，分析値にぞの程度の差が現われるかは， 分析值を評価する上に必要である。

そこで赤外分光器を 5 種類使い，装置と操作条件によ る分析值の変化を調へた。赤外分北器は. Perkin-Elmer 21 型 2 台 (PE-21，PE-21')，日本分光製 DS-402 G 回 折格子赤外分光器, 日本分光製 IR-S (簡易型), 日立製 EPI-S (簡易型)を用いた。まず同一装置で操作条件の及 を変えた場合は第 2 表に示されるように，分析值に医と んぞ差が現われないことがわかった。

次に分光器を変えた場合の分析值の差異を調べたが, これらは各分光器の通常定量拥いる条件で測定して求 めたものである。第 3 表で示されるように, シス $-1,4$ 含

\begin{tabular}{|c|c|c|c|c|c|c|c|}
\hline \multicolumn{2}{|c|}{ 操 作 条 件 } & A & $\mathrm{B}$ & $\mathrm{C}$ & $\mathrm{D}$ & $\mathrm{E}$ & $\mathrm{F}$ \\
\hline \multicolumn{2}{|c|}{ Speed $\left(\mathrm{sec} / 100 \mathrm{~cm}^{-1}\right)$} & 19.6 & 25.9 & 30.4 & 63.5 & 94.6 & 185.2 \\
\hline \multicolumn{2}{|c|}{ Suppresion } & 6 & 6 & 4 & 4 & 2 & 0 \\
\hline \multicolumn{2}{|c|}{ Gain } & 5 & 5 & 5 & 5 & 5 & 5 \\
\hline \multicolumn{2}{|l|}{ Response } & 1 & 1 & 1 & 1 & 1 & 2 \\
\hline \multicolumn{2}{|c|}{ Resolution } & 3 & 3 & 3 & 3 & 3 & 3 \\
\hline \multirow{4}{*}{$\begin{array}{c}\text { ミクロ構造** } \\
(\%)\end{array}$} & cis $-1,4$ & 95.3 & 95.6 & 95.8 & 96.0 & 95.6 & 95.6 \\
\hline & 1,2 & 2.2 & 1.9 & 1.7 & 1.8 & 2.0 & 1.9 \\
\hline & trans $-1,4$ & 2.5 & 2.4 & 2.5 & 2.2 & 2.4 & 2.5 \\
\hline & total found & 108.2 & 109.1 & 107.9 & 107.4 & 109.0 & 108.8 \\
\hline
\end{tabular}
有率の高い試料で分光器による差が見られた。また total found \% \& 分光器の分解能の大小に関係しておう，Morero らの吸光係数を用いた場合, 回折格子型分光器の上 うな高分解能の迷光のほとえどないものは $100 \%$ をが

第 2 表 操作条件による分析值の変化*

* 分光器 DS-402 G, ** 試料 BS \#3225 
第 3 表 各装置による共通ポリマーの分析

\begin{tabular}{|c|c|c|c|c|c|c|}
\hline & & IR-Sa) & DS $-402 G^{a)}$ & $\mathrm{PE}-21^{\text {a) }}$ & $\left.P E-21^{\prime b}\right)$ & EPI-S ${ }^{b)}$ \\
\hline \multirow{6}{*}{\multicolumn{2}{|c|}{$\begin{array}{l}\text { Resolution } \\
\text { Gain } \\
\text { Speed }\left(\mathrm{sec} / 100 \mathrm{~cm}^{-1}\right) \\
\text { Suppresion } \\
\text { Response } \\
\text { Slit Openning }\end{array}$}} & & 3 & 984 & 960 & $\therefore$ \\
\hline & & 5 & 5 & $5^{1 / 2}$ & 5 & 4 \\
\hline & & 46.3 & 30.4 & $40.0(\mathrm{sec} / \mu)$ & $59.0(\mathrm{sec} / \mu)$ & 45.0 \\
\hline & & & 4 & 2 & 2 & \\
\hline & & & 1 & 1. & 1 & \\
\hline & & & & & & \\
\hline 1000 & $\mathrm{~cm}^{-1}$ & 800 & 90 & $10 \mu \quad 222$ & $10 \mu \quad 167.0$ & 400 \\
\hline 900 & $\mathrm{~cm}^{-1}$ & 936 & 122 & $11 \mu \quad 266$ & $11 \mu \quad 196.5$ & 500 \\
\hline 800 & $\mathrm{~cm}^{-1}$ & 1716 & 153 & $12 \mu \quad 329$ & $12 \mu \quad 230.0$ & 700 \\
\hline 700 & $\mathrm{~cm}^{-1}$ & 3310 & 180 & $13 \mu \quad 420$ & $13 \mu \quad 288.5$ & 1100 \\
\hline & & & & $14 \mu \quad 539$ & $14 \mu \quad 386.5$ & \\
\hline & & & & $15 \mu \quad 1110$ & $15 \mu \quad 626.5$ & \\
\hline & cis $-1,4$ & 97.3 & 95.8 & 96.1 & 95.2 & 96.0 \\
\hline ミクロ構造* & 1,2 & 1.1 & 1.7 & 1.8 & 2.2 & 1.7 \\
\hline$(\%)$ & trans- 1,4 & 1.6 & 2.5 & 2.1 & 2.7 & 2.3 \\
\hline & total found & 98.5 & 107.9 & 105.8 & 102.8 & 97.6 \\
\hline
\end{tabular}

* 試料 BS\#3225

a) JSR 測定

b) BS 測定

第 4 表 各装置による各種ポリマーの分析值

\begin{tabular}{|c|c|c|c|c|c|}
\hline 試料 & 分 光 器 & cis $-1,4$ & 1,2 & trans $-1,4$ & total found \\
\hline \multirow[t]{4}{*}{$\mathrm{BS} \# 3182$} & $\left.\mathrm{PE}-21^{\prime} \mathrm{b}\right)$ & 96.0 & 1.6 & 2.4 & 101.6 \\
\hline & EPI-S b) & 95.8 & 1.8 & 2.4 & 100.7 \\
\hline & $\mathrm{PE}-21$ a) & 96.7 & 1.5 & 2.0 & 104.8 \\
\hline & IR-S a) & 97.0 & 1.5 & 1.5 & 98.4 \\
\hline \multirow[t]{4}{*}{ Ameripol $\mathrm{CB}$} & $\mathrm{PE}-21^{\prime}$ & 95.8 & 2.1 & 2.2 & 98.5 \\
\hline & EPI-S & 96.1 & 1.7 & 2.2 & 91.0 \\
\hline & $\mathrm{PE}-21$ & 95.7 & 2.2 & 2.3 & 116.7 \\
\hline & IR-S & 96.0 & 2.0 & 2.0 & 111.2 \\
\hline \multirow[t]{4}{*}{ Cis -4} & $\mathrm{PE}-21^{\prime}$ & 92.6 & 4.8 & 2.7 & 100.2 \\
\hline & EPI-S & 92.5 & 4.7 & 2.8 & 95.7 \\
\hline & $\mathrm{PE}-21$ & 93.4 & 4.4 & 2.2 & 106.2 \\
\hline & IR-S & 93.9 & 4.2 & 1.9 & 100.3 \\
\hline \multirow[t]{4}{*}{ Cisdene } & $\mathrm{PE}-21^{\prime}$ & 91.5 & 4.9 & 3.6 & 98.1 \\
\hline & EPI-S & 91.7 & 4.7 & 3.6 & 95.2 \\
\hline & $\mathrm{PE}-21$ & 92.5 & 4.4 & 3.1 & 106.0 \\
\hline & IR-S & 92.7 & 4.3 & 3.0 & 100.2 \\
\hline \multirow[t]{4}{*}{ Polymer Co. } & $\mathrm{PE}-21^{\prime}$ & 91.3 & 6.0 & 2.7 & 99.8 \\
\hline & EPI-S & 91.4 & 5.9 & 2.6 & 95.9 \\
\hline & PE-21 & 93.4 & 4.4 & 2.2 & 104.8 \\
\hline & IR-S & 92.6 & 5.6 & 1.8 & 101.8 \\
\hline \multirow[t]{2}{*}{ Budene 501} & $\mathrm{PE}-21^{\prime}$ & 85.2 & 6.1 & 8.7 & 101.2 \\
\hline & EPI-S & 84.9 & 6.0 & 9.2 & 95.8 \\
\hline
\end{tabular}
a) JSR 测定
b) BS 測定

Wol. 13, No. 145 
り上なわり, 簡易型分光器ではむしろ下まわることを知 的。

分光器による差がどのような傾向で現われるかを調べ るために, シス-1,4を多く含む試料 6 種について，4 種 類の分光器で測定してみた。第 4 表に示された分析值の ばらつきの原因としては, 分光器によるもの, 測定者に よるもの, 測定条件 (器具, 溶液など) などが学党られ る。しかし， PE-21，IR-S の測定が PE-21', EPI-S の
測定よりシスー 1,4 值が多くなる傾向が見られるので，も っとも大きなばらつきの原因は, 测定条件, 測定者の相 違によるといえよう。また簡易型分光器は一般にシスー 1,4 が少し多くなる傾向もみられた。

\section{5. 不純物の影響}

試料中によく含まれる不純物として；老化防止剂（主 として phenyl- $\beta$-naphthylamine (PBNA)) やンリュー

第 5 表 不純物の分析值に及ぼす影響

\begin{tabular}{c|c|c|c|c}
\hline \hline P B N A & cis-1,4 & 1,2 & trans-1,4 & total found \\
\hline 0 & 96.7 & 1.5 & 1.9 & 100.6 \\
1 & 96.6 & 1.5 & 1.9 & 101.4 \\
2 & 96.6 & 1.4 & 2.0 & 100.8 \\
3 & 96.9 & 1.3 & 1.9 & 104.0 \\
5 & 96.8 & 1.4 & 1.9 & 104.0 \\
10 & 97.2 & 1.2 & 1.6 & 115.9 \\
\hline
\end{tabular}

\begin{tabular}{c|c|c|c}
\hline \hline シリコングリース $(\%)$ & cis-1, & 1,2 & trans-1,4 \\
\cline { 1 - 2 } & 92.6 & 4.8 & 2.6 \\
2.06 & 92.6 & 4.7 & 2.7 \\
4.26 & 92.4 & 4.8 & 2.7 \\
6.59 & 92.1 & 4.8 & 3.1 \\
9.09 & 91.8 & 5.0 & 3.2 \\
\hline
\end{tabular}

第 6 表 Morero 法と簡便法の比較

\begin{tabular}{|c|c|c|c|c|c|c|}
\hline 料 & 解析 法 & 分光器 & cis $-1,4$ & 1,2 & trans $-1,4$ & total found \\
\hline BS \# 3182 & $\begin{array}{l}\mathrm{M} \\
\text { 簡 } \\
\mathrm{M} \\
\text { 簡 }\end{array}$ & $\begin{array}{l}\text { PE-21' } \\
\text { PE-21' } \\
\text { EPI-S } \\
\text { EPI-S }\end{array}$ & $\begin{array}{l}96.0 \\
95.8 \\
95.8 \\
96.4\end{array}$ & $\begin{array}{l}1.6 \\
1.8 \\
1.8 \\
1.4\end{array}$ & $\begin{array}{l}2.4 \\
2.4 \\
2.4 \\
2.2\end{array}$ & $\begin{array}{r}101.6 \\
101.8 \\
100.7 \\
93.7\end{array}$ \\
\hline Ameripol CB & $\begin{array}{l}\mathrm{M} \\
\text { 簡 } \\
\mathrm{M} \\
\text { 簡 }\end{array}$ & $\begin{array}{l}\text { PE-21' } \\
\text { PE-21' } \\
\text { EPI-S } \\
\text { EPI-S }\end{array}$ & $\begin{array}{l}95.8 \\
95.6 \\
96.1 \\
96.3\end{array}$ & $\begin{array}{l}2.1 \\
2.0 \\
1.7 \\
1.8\end{array}$ & $\begin{array}{l}2.2 \\
2.4 \\
2.2 \\
1.9\end{array}$ & $\begin{array}{l}98.5 \\
98.5 \\
91.0 \\
91.0\end{array}$ \\
\hline Budene 501 & $\begin{array}{l}\mathrm{M} \\
\text { 簡 } \\
\mathrm{M} \\
\text { 簡 }\end{array}$ & $\begin{array}{l}\text { PE-21' } \\
\text { PE-21' } \\
\text { EPI-S } \\
\text { EPI-S }\end{array}$ & $\begin{array}{l}85.2 \\
85.1 \\
84.9 \\
84.8\end{array}$ & $\begin{array}{l}6.1 \\
6.1 \\
6.0 \\
5.9\end{array}$ & $\begin{array}{l}8.7 \\
8.8 \\
9.2 \\
9.3\end{array}$ & $\begin{array}{r}101.1 \\
98.5 \\
95.8 \\
91.0\end{array}$ \\
\hline Cis -4 & $\begin{array}{l}\mathrm{M} \\
\text { 簡 } \\
\mathrm{M} \\
\text { 簡 }\end{array}$ & $\begin{array}{l}\text { PE-21' } \\
\text { PE-21' } \\
\text { EPI-S } \\
\text { EPI-S }\end{array}$ & $\begin{array}{l}92.6 \\
92.8 \\
92.5 \\
92.9\end{array}$ & $\begin{array}{l}4.8 \\
4.6 \\
4.7 \\
4.5\end{array}$ & $\begin{array}{l}2.7 \\
2.6 \\
2.8 \\
2.6\end{array}$ & $\begin{array}{r}100.2 \\
97.6 \\
95.7 \\
95.4\end{array}$ \\
\hline Cisdene & $\begin{array}{l}M \\
\text { 簡 } \\
M \\
\text { 簡 }\end{array}$ & $\begin{array}{l}\text { PE-21' } \\
\text { PE-21' } \\
\text { EPI-S } \\
\text { EPI-S }\end{array}$ & $\begin{array}{l}91.5 \\
91.5 \\
91.7 \\
91.6\end{array}$ & $\begin{array}{l}4.9 \\
4.9 \\
4.7 \\
4.8\end{array}$ & $\begin{array}{l}3.6 \\
3.6 \\
3.6 \\
3.6\end{array}$ & $\begin{array}{r}98.1 \\
104.6 \\
95.2 \\
99.9\end{array}$ \\
\hline
\end{tabular}


ングリースがある。完全に老化防止剂を取り去った試料 ではゲル化しやすく，測定を困難にする。これらの不純 物の分析值に及ぼす影響について調べた。

第 5 表に示されるように PBNA を混入すると, シスー 1,4 含有率を增加する傾向を示すが，少量の混入では, 任とんで影響を無視しうることがわかった。またシリュ ーングリースについても少量の混入は影響を与克ないこ ともかかった。市販ポリマー中に含をれている PBNA 量は普通 1 1.5\% 程度であるから,ゲルのない場合は 精製せず，そのます用いても分析值には大きく影響しな いといえよう。

\section{6. 簡便 Morero 法}

精密な分析を行なう場合には, Morero らの行なった と拉りの, 操作条件を用いる必要がある。装置, 操作条 件の異なる場合は Morero 々同様な手順で各吸光係数を 補正することが必要でめる。精密な分析を要せず，乙か も, 多数の分析を迅速行行ならためには，分析手順をで きるだけ簡便にして，しか子操作条件がかわっても分析 值の比較ができることが必要である。

これまでの例から，分析を簡単に行なうためには，つ ぎのような方法で行なっても十分な分析值が得られるこ とがわかった。まず，試料の精製は行なわず，そのまま 二硫化炭素溶液とする。測定セルは $\mathrm{NaCl}$ 固定セル 0.5 〜 $1 \mathrm{~mm}$ の比較的厚さのそろったものを用い試料側に少 乙厚い方を用いる。分光器の操作は普通の条件でよく, とくに scan speed を落す必要はない。分光器は大型の みでなく簡易型でもよい。

このように手順を簡単にした場合とMorero の方法ど おりの手順で行なった結果を比較すると符 6 表のように なる。両者間の誤差は, 第 6 表に示されるようにきわめ てわずかで簡便法で十分であることがわかった。

\section{7. おわりに}

赤外分光光度法でポリブタジェンのミクロ構造を分析
する場合, 同一試料, 同一分析法を採用しても, 分光器 オペレーター，試料精製法などの差異により分析值は多 少変化する。したがってポリブタジェンのミクロ構造組 成の小さい差異を文献を比較して論ずることはむつかし いことである。シス $-1,4$ ポリブタジェンのミクロ構造 を問題にする場合にもこのことが問題になる。一般に新 規な立休規則性触媒で得たポリマーのミクロ棒造の純度 を論ずるときには同時に測定した広く市販されている標 準となるポリマーの分析值も添付することは望をしいこ とである。このようなミクロ構造分析のあいまいさは， たんにポリブタジェンの場合のみならず他のポリマーに ついてもあてはまることである。最近の高分子合成技術 の進歩はめざましく，ポリマーの種類も著しく多種多様 化しつつある。ポリマーの物性はそのミクロ構造によっ て大きく支配されているのでミク口構造分析法のいっそ うの進歩を期待してやまない。

以上ポリブタジェンのミクロ構造分析の問題点につい て考察してきたが，同様な問題がポリイソプレンの場合 にもある。これまでのポリイソプレンの赤外分析方法で は, シス $-1,4$ とトランス-1,4 の区別が困難であり，さ らに正確な分析方法の研究が必要とされている。このた め新しい分析方法について現在研究中である。

\section{文献}

1) J. N. Short, V. Thornton, G. Kraus: Rubber Chem. Tech., 30, 1118 (1957)

2) R. R. Hampton: Anal. Chem., 21, 923 (1949)

3) J. L. Binder: Anal. Chem., 26, 1877 (1954)

4) W.S. Richardson: J. Polymer Sci., 13, 229 (1954)

5) R. S. Silas, J. Yates, V. Thornton: Anal. Chem., 31, 529 (1959)

6) D. Morero, A. Santambrogio, L. Porri, F. Clampelli : Chim. $e$ Ind., 41, 758 (1959)

7) G. Natta, et al.: Rubber and Plastic Age, 42, 402 (1961)

40) M. Smoluchowski: Z. phys. Chem., 92, 129 (1918)

41) 西島安則, 滝 文夫, 小野水禎彦: 涞発棐

42) J. Q. Umberger, V. K. La Mer: J. Am. Chem. Soc., 67, 1099 (1945)

43) G. Oster: Trans. Faraday Soc., 47, 660 (1951)

44) E. J. Bowen, A. Norton: Trans, Faraday Soc., 35, 44 (1939)

45) H. Weil-Malherbe, J. Weiss : Nature, 149, 471 (1942)

46) W. R. Ware: J. Phys. Chem., 66, 455 (1962)

47) M. V. Anufrieva, A. D. Zaitseva: Izvest. Akad. Nauk. S.S.S.R., Ser. Fiz., 24, 755 (1960)

48) G. Oster, N. Geacintov, A. U. Khan: Nature, 196, 1089 (1962)

49) C. Czarnecki, M. Kryszewski : J. Polymer Sci., Part A, 1, 3067 (1963) 